\title{
Conodonta, Trilobita, and Anthozoa near the Late Frasnian Upper Kellwasser Event of the Geipel Quarry section in Schleiz, Thuringian Mountains (Germany)
}

\author{
Dieter Weyer ${ }^{1}$, Raimund Feist ${ }^{2}$ \& Catherine Girard $^{3}$
}

With 2 figures and 1 plate

\begin{abstract}
New recoveries of Trilobita, Anthozoa and Conodonta from the linguiformis Zone close to the Frasnian/Famennian boundary and immediately preceding the Upper Kellwasser Event level at Schleiz (Thuringia) are investigated. The trilobites species are Harpes neogracilis Richter \& Richter, 1924, Palpebralia cf. brecciae (Richter, 1913) and Acuticryphops acuticeps (Kayser, 1889), the latter is represented by several morphs with different numbers of eye-lenses; the trend to eye-reduction is discussed. The Rugosa fauna that was nearly unknown from the psychrospheric facies worldwide, comprise six taxa of the Cyathaxoniina. The rich conodont faunas permit tracing the exact boundary between the top of the Late Palmatolepis rhenana Zone and the Palmatolepis linguiformis Zone.
\end{abstract}

Key words: Late Frasnian, conodonts, trilobites, corals, biostratigraphy, Thuringian Mountains.

\section{Zusammenfassung}

Im Niveau der Frasnium/Famennium-Grenze werden neue Fossilfunde der letzten Trilobita, Anthozoa und Conodonta aus der linguiformis-Zone (vor dem Oberen Kellwasser-Event) mitgeteilt. Harpes neogracilis Richter \& Richter, 1924, Palpebralia cf. brecciae (Richter, 1913) und Acuticryphops acuticeps (Kayser, 1889) wurden beobachtet; bei letzterem wird an Hand verschiedener Morphen mit unterschiedlicher Linsenzahl der Trend zur Augenreduktion diskutiert. Von der Rugosa-Fauna, die weltweit aus solcher psychrosphaerischer Fazies fast unbekannt blieb, sind sechs Taxa der Cyathaxoniina skizziert. Die reichen Conodonta-Faunen erlauben eine präzise Grenzziehung zwischen dem Top der Late Palmatolepis rhenana-Zone und der Palmatolepis linguiformis-Zone.

Schlüsselwörter: Late Frasnium, Conodonta, Trilobita, Anthozoa Rugosa, Biostratigraphie, Thüringer Schiefergebirge.

\section{Introduction}

Since the first investigations at the end of the $18^{\text {th }}$ century (Walch 1769), several sections of historical importance for the stratigraphical exploration in the Thuringian Slate Mountains of course have disappeared. Even today it might be difficult sometimes to preserve such outcrops as geological monuments under the law of protected nature reservations. Among Upper Devonian sequences deplorably lost at the northwestern flank of the Berga Anticline, there are to mention the exposures of the "Planschwitz" beds near Kirschkau (Geinitz 1853), the former Eulenbusch Quarry (Müller 1956) and the outcrop of Alte Heerstraße (Brügge 1973), both near Öttersdorf, and now in part also the former Geipel Quarry in Schleiz (Frasnian-Famennian boundary of Müller 1956 still accessible, Wocklumeria "Stufe" of Weyer 1981 at the entrance passage vanished). Therefore, a perhaps final fossil collecting was organized in 1995 , with special reference to the once locally famous macrofauna (ammonites, trilobites, but now including also corals), all controlled by rich conodont communities.

\footnotetext{
${ }^{1}$ Löwestrasse 15, D-10249 Berlin, Germany. E-mail: dieter.weyer@t-online.de

${ }^{2}$ Institut des Sciences de l'Évolution, Université de Montpellier 2, F-34095 Montpellier, France. E-mail: rfeist@isem.univ-montp2.fr

${ }^{3}$ Université Claude Bernard-Lyon I, Laboratoire de Paléoenvironnements et Paléobiosphère, 2, rue Raphael Dubois, F-69622 Villeurbanne Cedex, France. E-mail: c-girard@univ-lyon1.fr Received March 2003, accepted June 2003
} 


\section{Geipel Quarry section in the town of Schleiz}

The Geipel Quarry Locality was first mentioned in 1915 by Ernst Zimmermann (18601944), renowned geologist with the Prussian Geological Survey in Berlin. He considered the Upper Devonian sequence exposed in the quarry as one of the very few suitable reference sections for the region along the northwestern flank of the Berga Anticline in the Eastern Thuringian Slate Mountains, editing the special geological map (scale 1:25000) of sheet Schleiz (Zimmermann 1915: 39 , with record of Late Frasnian ammonoids). The quarry is named after the owner, a well known businessman in Schleiz. In those days the quarry was situated just outside the western city gate; since then the quarry has became part of
Schleiz and was abandoned prior to 1945 . Some landscaping took place on the quarry after construction of a private house.

Schindewolf (1921: 172) actualized the local Frasnian ammonoid faunal list, based on own collections, rendered his trilobite material to the Richters (Richter \& Richter 1926: 285), and later initiated the dissertation of Müller (1956), which includes a refined lithostratigraphy (Fig. 1) and a richer macrofaunal approach just before the start of conodont micropalaeontology (Helms 1961, then Schülke 1995). The section of Müller (1956) was also used by Blumenstengel et al. (1963: 29), Schlegel \& Wiefel (1998: 273) and Bartzsch et al. (2002: 310); the actual outcrop became more and more incomplete under debris cover.
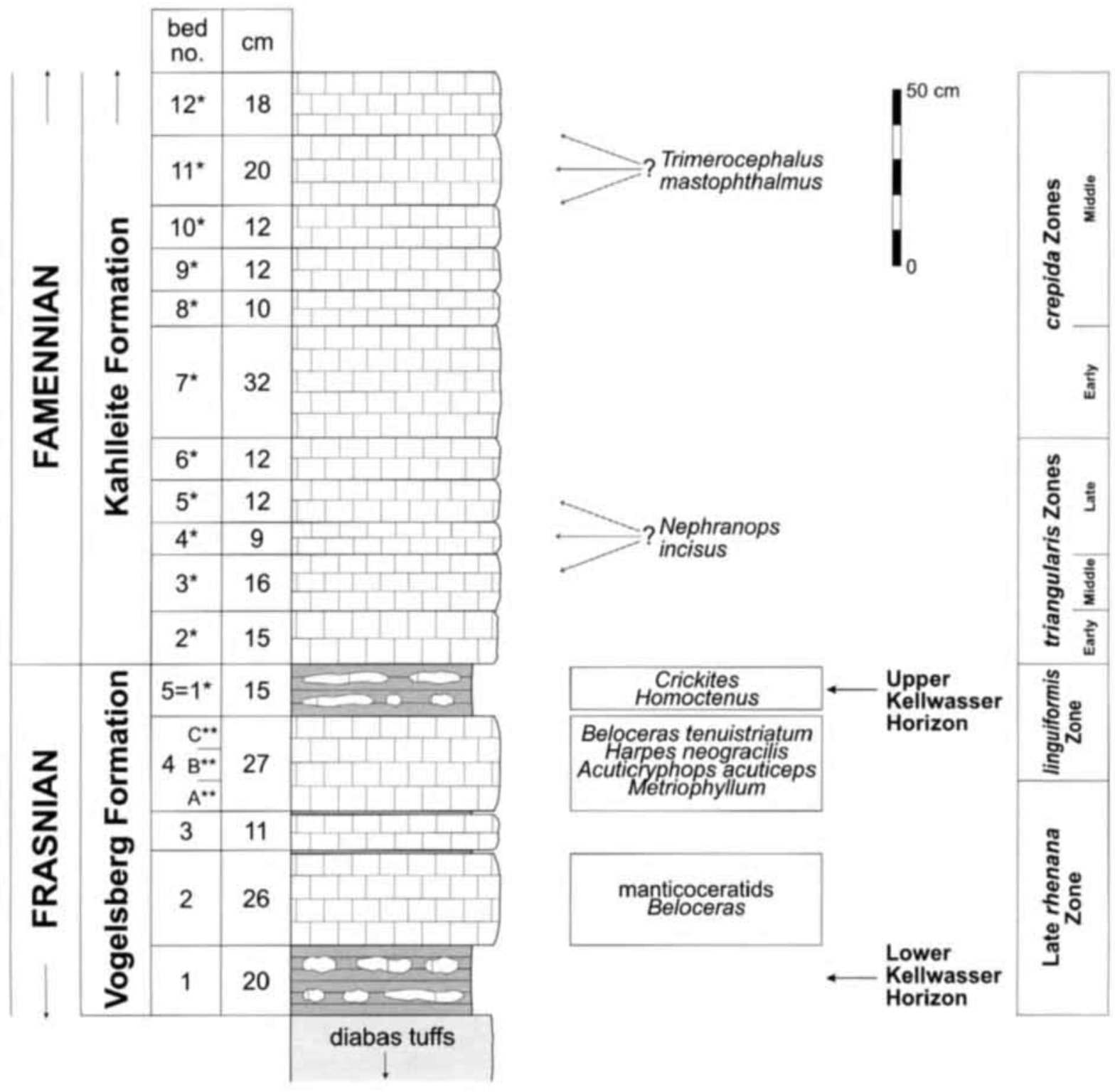

Fig. 1. Lithostratigraphy of the extremely condensed Frasnian-Famennian boundary beds (cephalopod limestone facies) in the abandoned Geipel Quarry in Schleiz (southern wall), compiled after Müller (1956: bed 1-5), Schülke (1995: bed 1*-12*) and Weyer (field work 1995: bed $4 \mathrm{~A}^{* *}-\mathrm{C}^{* *}$ ). After Bartzsch et al. (2002: 310, fig. 3, with some modifications). 
New collections of Weyer (in 1995) focused on corals. Ammonoids (Crickites, Beloceras, Tornoceratids) were rendered to Prof. Dr. R. T. Becker (Münster). The fauna is deposited in the Museum of Natural History (Palaeontology) of Humboldt University, Berlin (Anthozoa, Trilobita - numbers MB.) and in the collections of the Palaeontological Institute, University Claude Bernard, Lyon (Conodonta - numbers UL FGW...).

\section{Conodonts}

It is well established that in Frasnian/Famennian boundary sections of Rhenohercynian Avalonia (such as Martenberg, Steinbruch Schmidt, Sessacker, Benner Quarry near Bicken, and Burg Berg in the Rhenish Slate Mountains) the latest Frasnian linguiformis Zone starts with its index form, Palmatolepis linguiformis Müller, 1956 not far below the base of the Upper Kellwasser Horizon (Ziegler \& Sandberg 1990). The relative abundance of Palmatolepis linguiformis in these localities on the Laurussian epicontinental margin seems to be related to the transgressive pulse that preceded the Upper Kellwasser Event (Racki et al. 2002).

In contrast, Palmatolepis linguiformis is mostly absent in North Gondwana derived terranes and in particular in the Frasnian/Famennian boundary stratotype arca at Coumiac, Southern France (House et al. 2000). However it has recently been established in the Carnic Alps (Pramosio A section; Spalletta \& Perri 1998) and in the Canning Basin of NW Australia (Klapper 1995), both related to the Northern Gondwana margin. Here we document the presence of Palmatolepis linguiformis in another terrane that derived from North Gondwana, the Saxothuringian unit that was part of the Armorican plate-assemblage (Franke 1999, Linnemann \& Heuse 2000: fig. 1).

Records of Palmatolepis linguiformis Müller, 1956 from the Thuringian Mountains go back to 1963 but only appear in generalized faunal lists, without precise data concerning locality and horizon. The first note of Helms (1961: 40) even remained unpublished, although it was well known to local stratigraphers. Helms later (1963: fig. 2/12) provided an illustration of Palmatolepis (Manticolepis) linguiformis from the Berga Anticline and (in Blumenstengel et al. 1963: 32, fig. 2/2) mentioned the species as an index fossil for the middle parts of the "Upper rhenana Zone" (sensu Ziegler 1962: 23); this chart was copied by
Blumenstengel (in Steinbach 1974: fig. 33) and was cited by Pfeiffer (1967: tab. 3) and Wiefel (1976: 549). Schülke (1995: 16, fig. 12) indicated the presence of the linguiformis Zone in a revised section of the Geipel Quarry in Schleiz (beds 4-5), but without naming the species itself in his faunal list (107, tab. 5). Bartzsch et al. (2001: 104, fig. N1-16, 111) recorded Palmatolepis linguiformis in the section of Kahlleite Quarry near Rödersdorf (studied by M. Gereke), and an upper linguiformis Zone interval without the index species in the section of Vogelsberg Quarry near Göschitz (studied by E. Schindler and the late W. Ziegler) - it is interesting to see this knowledge coming back as a new result to Thuringia, where in reality it was born already 38 years ago. Based on rich unpublished faunas from the Vogelsberg and Kahlleite sections, Bartzsch et al. (2002: 310, fig. 2, 312) reported the linguiformis Zone (with its index conodont) from the uppermost layers of the Vogelsberg Formation, just below the Upper Kellwasser Horizon.

In the Geipel Quarry of Schleiz, latest Frasnian conodonts including Palmatolepis linguiformis were recovered from Bed 4, immediately below the Upper Kellwasser Horizon. This bed is extremely rich in conodonts throughout, but Palmatolepis linguiformis appears not earlier than in the middle part of the bed (level 4B). This allows us to precisely define the base of the latest Frasnian linguiformis Zone, which starts as elsewhere shortly before the beginning of the hypoxic Upper Kellwasser bed (Bed 5) emphasising its contemporaineity in palaeogeographically distinct plate units.

Associated conodonts in Bed 4 such as Palmatolepis bogartensis (Stauffer, 1938), Ancyrodella curvata (Branson \& Mehl, 1934), Ancyrognathus asymmetricus (Ulrich \& Bassler, 1926) and Palmatolepis rhenana Bischoff, 1956 (figured on plate 1) are abundant in the Palmatolepis linguiformis Zone as expected from the standard zonation Ziegler \& Sandberg (1990), and in MN Zone 13 (Klapper, 1989). Comparing the taxonomic diversity and abundance conodont biofacies indicates clear dominance of palmatolepids that tends to increaseaugment towards the top of the Bed 4 at the expense of Polygnathus. This trend is seen in offshore sections including Coumiac, Montagne Noire (Girard \& Feist, 1997), Mrirt, Moroccan Meseta (Lazreq, 1992), and Steinbruch Schmidt, Rhenish Slate Mountains (Sandberg et al. 1988), and may correspond to a general sea-level rise prior to the Upper Kellwasser event level. 


\section{Trilobites}

The first determined trilobite from the Late Frasnian of the Geipel Quarry is Phacops acuticeps (Zimmermann 1915: 41). Trilobites collected by Schindewolf, in ca. 1920 were attributed by Richter \& Richter (1926: 285) to "Proetus" (gen.?) sp. indet., Harpes neogracilis and Phacops (Cryphops) acuticeps. Müller (1956) logged and sampled the section in great detail, and in the process discovered Frasnian trilobites [Phacops (Cryphops) acuticeps and Phacops (Phacops) cryphoides] in the last $40 \mathrm{~cm}$ (Bed 4) below the Upper Kellwasser Horizon (Bed 5). Exhaustive collecting from the same bed by one of us (D. W.) garnered 77 trilobite specimens of Acuticryphops acuticeps (Kayser, 1889) (74\%), Harpes neogracilis Richter \& Richter, 1924 (10.4\%) and Palpebralia cf. brecciae (Richter, 1913) $(9.1 \%)$; the remaining $6.5 \%$ represents pygidia of an undetermined phacopid species (?Phacops cryphoides Richter \& Richter, 1926).

This fauna (Pl. 1: Fig. 1-10) though poorly diversified typically occurs in the latest Frasnian before its extinction at the base of the Upper Kellwasser Horizon both in the Rhenish Slate Mountains and Harz Mountains (Steinbruch Schmidt, Beul, Sessacker, Aeke) and on the North Gondwana margin (Coumiac, Mrirt) (Feist \& Schindler 1994, Feist 2002). It is characterized in particular by trends to eye reduction that let to blindness in last representatives of Palpebralia in the Palmatolepis linguiformis Zone. The spectacular regression and inconstancy in the number of eye-lenses in Acuticryphops observed in Coumiac and Mrirt exist also in Schleiz where in Bed 4 morphs with a maximum number of 14 lenses and a minimum of 5 lenses (mean: $9,15)$ co-occur. However the material is insufficient as to decide whether there is a trend in mean eye-lens reduction within Bed $4 \mathrm{~A}-\mathrm{C}$. In comparison to contemporaneous faunas from Coumiac and Mrirt the population in Bed 4 is distinct by a poorer taxonomic diversity, a predo- minance of Acuticryphops acuticeps that outnumbers by far the other taxa, and the much higher mean number of eye-lenses (unlike the populations in Coumiac and Mrirt where most morphs possess less than 6 lenses). It can be stated with new evidence from Thuringia that last trilobite populations from deeper outer shelf habitats that precede the Upper Kellwasser extinction exhibit evolutionary trends to eye-reduction globally but to different extent depending on local environmental conditions.

\section{Corals}

Zimmermann (1915: 41, "kleine Einzelkorallen, Cyathophyllum sp.") found the first Rugosa at Geipel Quarry. Schindewolf studied one of these specimens and some additional corals of his own including a few thin sections of the genus Metriophyllum (unpublished material in Berlin museums). Weyer (1984: 18) recorded rich new, but so far unstudied samples from the Late Frasnian cephalopod limestone facies of the Berga Anticline (Geipel and Vogelsberg Quarries), with Metriophyllum, Metrionaxon, Metrioplexus, and Neaxon-like taxa. The occurrence of Metriophyllum (Bartzsch et al. 2002: 311) in the Vogelsberg Formation refers to unpublished collections of Weyer from three localities (Geipel Quarry in Schleiz, Vogelsberg Quarry near Göschitz, Kahlleite Quarry near Rödersdorf).

The community of Rugosa corals (Fig. $2 \mathrm{~A}-\mathrm{H}$ ) from Bed 4 of Geipel Quarry in Schleiz consists of undescribed taxa and includes Neaxon Kullmann, 1965, Petraia Münster, 1839, Metrionaxon Glinski, 1963, Metriophyllum Milne-Edwards \& Haime, 1850, at least two new genera, and some breviseptoid/ampleximorph taxa. However, current taxonomic studies will be based predominantly on the much richer and better preserved material of the neighbouring locality Vogelsberg Quarry near Göschitz; there the same coral species were also found in somewhat older beds

Plate 1. 1-2, Palpebralia cf. brecciae (Richter, 1913). 1, fragmentary cephalon, internal mould, MB.T.4712, dorsal view, $\times 5.1$, level 4B; 2, pygidium, MB.T.4713, dorsal view, $\times 10$, level 4B. 3-5, 9-10, Acuticryphops acuticeps (Kayser, 1889). 3, cephalon, MB.T.4714, ventral view showing vincular furrow and ventral plate, $\times 5.5$, level 4A; 4-5, cephalon, MB.T.4715, dorsal view, $\times 6$, and lateral view, $\times 6.8$, level $4 \mathrm{~A} ; 9-10$, fragmentary ceplon, MB.T.4716, lateral view, $\times 8.2$, and dorsal view, $\times 9.5$, level 4A. 6-8, Harpes neogracilis Richter \& Richter, 1924. 6, fragmentary cephalon, MB.T.4717, dorsal view, $\times 3.5$, and lateral view, $\times$ 3.6, level 4A. 11, Palmatolepis bogartensis (Stauffer, 1938), UL FGW12, upper view, $\times 3$, level 4A. 7-8, fragmentary cephalon, MB.T.4718, dorsal view, $\times 40$, level 4B. 12, Palmatolepis linguiformis Müller, 1956, UL FGW02, upper view, $\times 60$, level 4B. 13, Palmatolepis linguiformis Müller, 1956, UL FGW01. upper view, $\times 60$, level 4B. 14, Palmatolepis rhenana Bischoff, 1956, UL FGW16, upper view, $\times 50$, level 4B. 15, Ancyrognathus asymmetricus (Ulrich \& Bassler, 1926), UL FGW05, upper view, $\times 50$, level 4B. 16, Ancyrodella curvata (Branson \& Mehl, 1934), UL FGW07, upper view, $\times 50$, level 4B (all specimens from the former Geipel Quarry in Schleiz, Vogelsberg Formation, bed 4). 


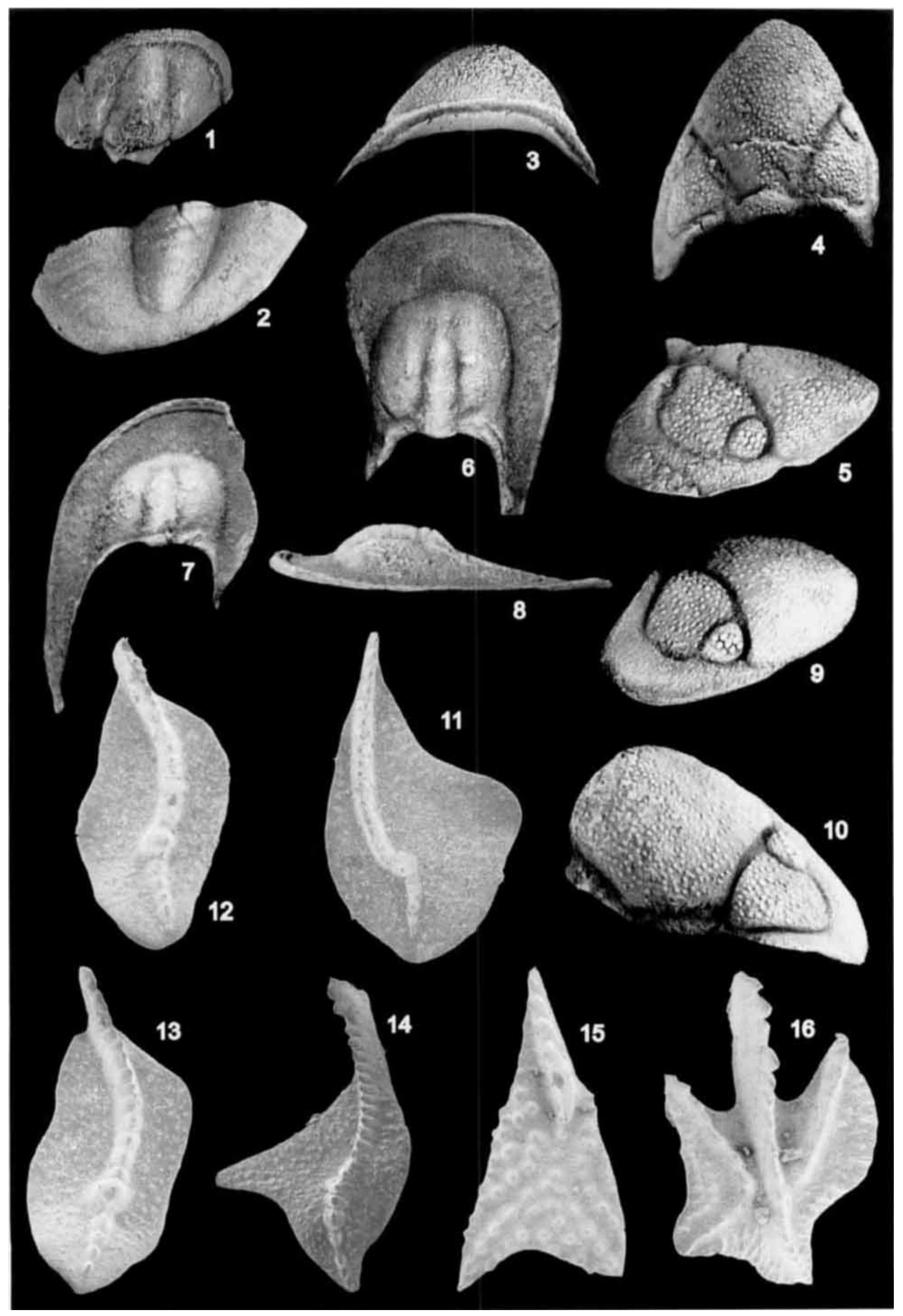



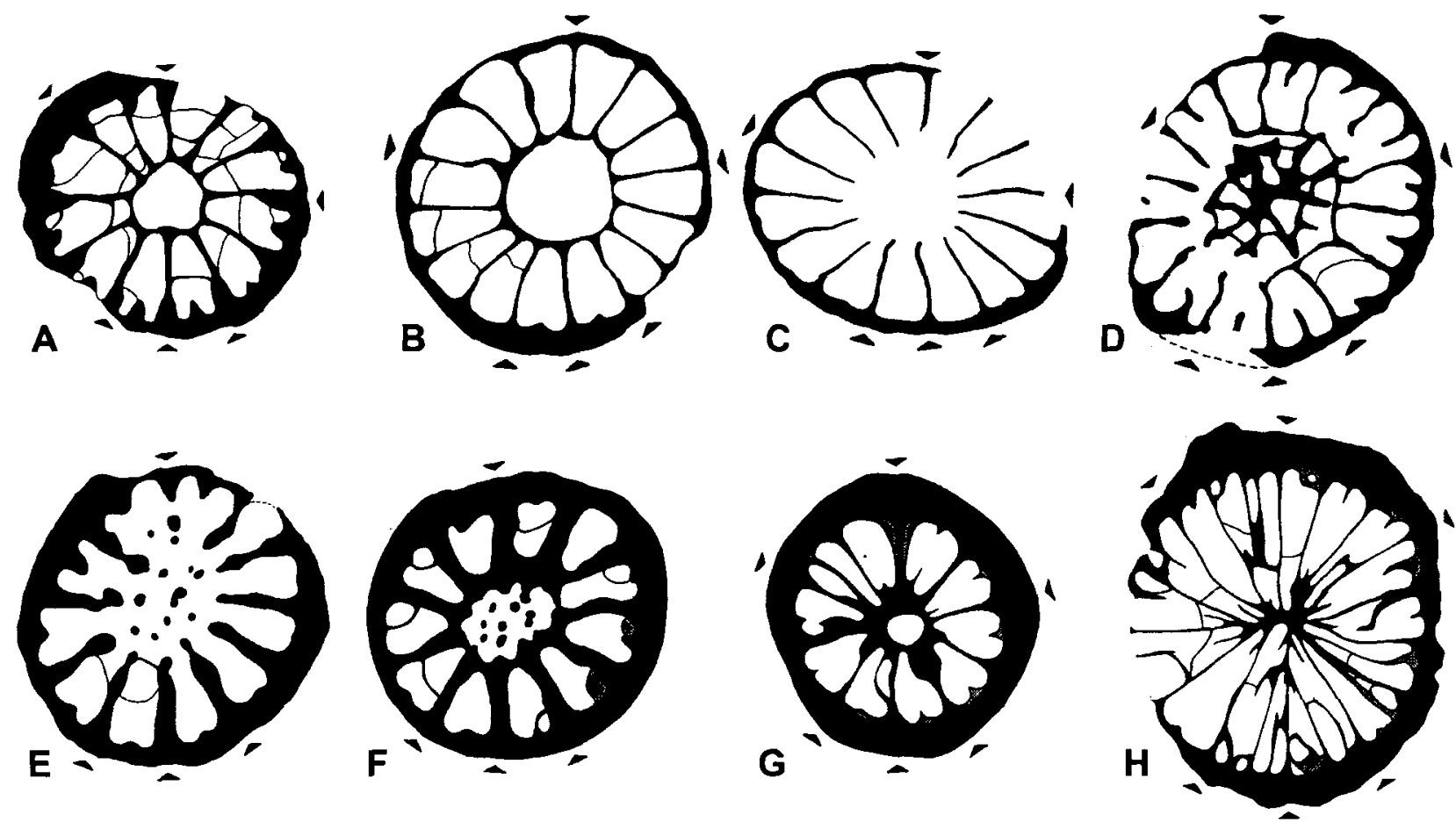

Fig. 2. Rugosa (Anthozoa) from the uppermost Frasnian cephalopod limestones (Vogelsberg Formation, bed no. 4) in the Geipel Quarry of Schleiz, NW flank of Berga Anticline. Thuringian Mountains, coll. Weyer 1995 (Museum of Natural History, Humboldt University, Berlin). Palmatolepis linguiformis Zone (bed 4C - Fig. D), top of Late Palmatolepis rhenana Zone (bed 4A - Figs. B-C, E-H), and undifferentiated same Late Frasnian interval (bed 4 - Fig. A). A, Neaxon sp., subtabular cross section. $\times 10$. B-C, Petraia? sp., subtabular and calicular cross sections, $\times 8$ and $\times 7$. D, nov. gen. nov. sp. I, subtabular cross section, $\times 12$. E-F, nov. gen. nov. sp. II, subtabular cross sections, $\times 9$. G. Metrionaxon sp., subtabular cross section, $\times 12$. $\mathbf{H}$, Metriophyllum sp., subtabular cross section, $\times 8$.

(below the Lower Kellwasser Horizon). The first new genus (I) with a remarkable axial structure is close to the Columnaxoninae Weyer, 1980 (related to Laccophyllinae Grabau, 1928, within the Cyathaxoniidae Milne-Edwards \& Haime, 1850). To date the sole similar and comparable taxon is Cyathaxonia? hercynica Roemer, 1855 from the Middle Givetian (Weyer \& Zagora 1990: 27, fig. 3); this rare species occurs from the Harz and Rhenish Mountains in Germany to southern France (Montagne Noire) and Morocco (Anti-Atlas). The second new genus (II) with strong axial trabeculae and a slightly inconstant aulos belongs to the Neaxon group. Metriophyllum is used in the revised interpretation of Weyer (1996: 86), being a member of the Lindstroemiidae Počta 1902, close to Lindstroemia Nicholson \& Thomson, 1876 (with synonym Lopholasma Simpson 1900).

Worldwide, psychrospheric coral associations of this Cyathaxonia facies type (sensu Hill 1938: 5-12) remained nearly unknown in the Frasnian (and also in the Givetian). Therefore, Sorauf \& Pedder (1986: 1267) speculated about a possible late origin of basinal faunas in the Famennian, but they existed throughout all the Devonian (and Silurian), and were described only excep- tionally by very few authors, often of ancient times without modern morphological revisions. The first thorough record for the Early Frasnian (including now late Givetian Pharciceras beds) in ammonoid facies was given, already in the period before use of thin sections, by Ludwig (1865-1866: 9 nearly forgotten, never redescribed coral taxa from the Rhenish Mountains). Weissermel (1939) introduced 3 new taxa from the Thuringian Mountains, based on badly preserved steinkern samples in the stratigraphically well studied sections of Volk (1939). More adequate studies (with thin sections) start with Stainbrook (1946: Iowa), Soshkina (1952: Ural Mountains), Bulvanker (1958: Kuznezk Basin), Holwill (1964: Western Europe), and Ivaniya (1965: Kuznezk Basin) up to the lately paper of Hill \& Jell (1971: Canning Basin) they described new species of Amplexus, Caninia, Catactotoechus, Metriophyllum, Nalivkinella, Nicholsoniella, Syringaxon. Perhaps, Syringaxon independense Stainbrook, 1946 can be transferred to Petraia Münster, 1839 (in the revised sense of Weyer, 2000). At present and momentary, the diverse Late Frasnian Rugosa assemblage from the Thuringian Mountains seems to be unique in the world. 


\section{Conclusions}

The presence of Palmatolepis linguiformis, the index taxon of the latest Frasnian Palmatolepis linguiformis Zone, is documented in Thuringia, a part of the Armorican Plate Assemblage. As in the Avalonian Rhenish Slate Mountains it occurs immediately below the Upper Kellwasser Horizon and is associated, as elsewhere, with the same widely distributed trilobite association characterized by trends towards reduced sight. By contrast, the presence of a diversified deep-water coral fauna in the same level is unusual and poorly known from sections outside Thuringia.

\section{References}

Bartzsch, K., Blumenstengel, H., Gereke, M., Schindler, E., Weyer, D. \& Ziegler, W. 2001. Post-conference field trip (N, part 1): Thüringer Schiefergebirge. In Jansen, U., Königshof, P., Plodowski, G. \& Schindler, E. (eds). Field trips guidebook. - 15th International Senckenberg Conference May 11-21, 2001 "Mid-Palaeozoic Bio- and Geodynamics, The North Gondwana - Laurussia Interaction", Joint Meeting International Geological Correlation Programme (IGCP), No. 421 and Subcommission on Devonian Stratigraphy (SDS): 87-113; Frankfurt am Main.

Bartzsch, K., Blumenstengel, H. \& Weyer, D. 2002. Stratigraphie des Oberdevons im Thüringischen Schiefergebirge. Teil 2: Berga-Antiklinorium. - Beiträge zur Geologie von Thüringen, Neue Folge 8: 303-327 (dated 2001).

Blumenstengel, H., Helms, J. \& Zagora, K. 1963. Exkursion 2. Biostratigraphie und Fauna vom Silur bis zum tieferen Unterkarbon am NW-Rand des Bergaer Sattels. - Exkursionsführer, Herbst-Tagung Leipzig, Geologische Gesellschaft der DDR "Biostratigraphie des ostthüringisch-vogtländischen Paläozoikums": 27-40; Berlin.

Brügge, N. 1973. Zur stratigraphischen Einstufung des Oberdevon-Profils „Alte Heerstraße“ bei Schleiz, Bezirk Gera. Zeitschrift für geologische Wissenschaften 1 (3): 319-327.

Bulvanker, E. Z. 1958. Devonskie chetyrekhluchevye korally okrain Kuznetskogo basseyna. [Devonian tetracorals from the border of the Kuznezk basin]. - Vsesoyuznyy Nauchno-Issledovatel'skiy Geologicheskiy Institut (VSEGEI); 1-212, atlas; Leningrad [VSEGEI, Rotaprint].

Feist, R. 2002. Trilobites from the latest Frasnian Kellwasser Crisis in North Africa (Mrirt, central Moroccan Meseta). - Acta Palaeontologica Polonica 47 (2): 203-210.

Feist, R. \& Schindler, E. 1994. Trilobites during the Frasnian Kellwasser Crisis in European Late Devonian cephalopod limestones. - Courier Forschungsinstitut Senckenberg 169 (Willi Ziegler Festschrift II): 195-223.

Franke, W. 1999. Tectonic and Plate Tectonic Units at the North Gondwana Margin: evidence from the Central European Variscides. In Feist, R., Talent, J. A. \& Daurer, A. (eds). North Gondwana: Mid-Palaeozoic Terranes, Stratigraphy and Biota. - Abhandlungen der Geologischen Bundes-Anstalt Wien 54: 7-13.

Geinitz, H. B. 1853. Die Versteinerungen der Grauwackenformation in Sachsen und den angrenzenden Länder-Abtheilungen. Heft II. - 1-95; Verlag Wilhelm Engelmann, Leipzig.

Girard, C. \& Feist, R. 1997. Eustatic trends in conodont diversity across the Frasnian-Famennian boundary in the stratotype area. - Lethaia 29: 329-337.
Glinski, A. 1963. Neue Gattungen der Metriophyllidae (Rugosa) aus dem Devon des Rheinlands. - Senckenbergiana Lethaea 44 (4): 321-339.

Grabau, A. W. 1928. Palaeozoic Corals of China. Part I. Tetraseptata II. Second contribution to our knowledge of the Streptelasmoid Corals of China and Adjacent Territories. - Palaeontologica Sinica, series B 2 (2): 1-175.

Helms, J. 1961. Conodonten-Stratigraphie. Eine rückschauend wertende Betrachtung und neue spezielle Ergebnisse aus dem Oberdevon Thüringens. - 143 pp.; Unpublished Dissertation, Faculty of Mathematics and Natural Sciences, Humboldt University Berlin.

- 1963. Zur "Phylogenese" und Taxionomie von Palmatolepis (Conodontida, Oberdevon). - Geologie (Berlin) 12 (4): 449-485

Hill, D. 1938-1941. A monograph on the Carboniferous rugose corals of Scotland. - The Palaeontographical Society London [Monographs]: 1-213 [91, (for 1937. 412): 1-78; 1938; 92 (for 1938, 416): 79-114, 1939; 94 (for 1940, 419): 115-204, 1940; 95 (for 1941, 424): 205-213, 1941].

Hill, D. \& Jell, J. S. 1971. Devonian corals from the Canning Basin, Western Australia. - Bulletin, Geological Survey of Western Australia 121: 1-158 (dated 1970).

Holwill, F. J. W. 1964. The Coral genus Metriophyllum Edwards and Haime. - Palacontology (London) 7 (1): $108-123$.

House, M. R., Becker, R. T., Feist, R., Flajs, G., Girard, C. \& Klapper, G. 2000. The Frasnian/Famennian boundary GSSP at Coumiac, Southern France. In Bultynck, P., (ed.). Subcommission on Devonian Stratigraphy, Recognition of Devonian series and stage boundaries in geological areas. - Courier Forschungsinstitut Senckenberg 225: 59-75.

Ivaniya, V. A. 1965. Devonskie korally Rugosa Sayano-Altayskoy gornoy oblasti. [Devonian Rugosa corals from the Sayan-Altai mountain region]. - 1-398; Izdatel'stvo Universiteta, Tomsk.

Klapper, G. 1989. The Montagne Noire Frasnian (Upper Devonian) conodont succession. In McMillan, N. J., Embry, A. F. \& Glass, D. J. (eds). Devonian of the World. Canadian Society of Petroleum Geology, Memoir 14 (3): $449-468$.

- 1995. Preliminary analysis of Frasnian, Late Devonian conodont biogeography. - Historical Biology (Amsterdam) 10: $103-107$.

Kullmann, J. 1965. Rugose Korallen der Cephalopodenfazies und ihre Verbreitung im Devon des südöstlichen Kantabrischen Gebirges (Nordspanien). - Akademie der Wissenschaften und der Literatur [in Mainz], Abhandlungen der mathematisch-naturwissenschaftliche Klasse 1965 (2): 33-168.

Lazreq, N. 1992. The Upper Devonian of Mrirt. In Ziegler. W. (ed.). Papers on Palaeozoic Conodonts from Eurasia and North Africa. - Courier Forschungsinstitut Senckenberg 154: 107-123.

Linnemann, U. \& Heuse, T. 2000. The Ordovician of the Schwarzburg Anticline: Geotectonic setting, biostratigraphy and sequence stratigraphy (Saxo-Thuringian Terrane, Germany). - Zeitschrift der Deutschen Geologischen Gesellschaft 154 (4): 471-491.

Ludwig, R. 1865-1866. Corallen aus paläolithischen Formationen. - Palacontographica, 14 (4, 5, 6): 133-244. $249-252$ [133-172 november $1865 ; 173-212$ march 1866 ; $213-244,249-252$ may 1866$]$.

Milne-Edwards, H. \& Haime, J. 1850-1855. A Monograph of the British Fossil Corals. - The Palaeontographical Society [Monographs]: I-LXXXV, 1-322; London.

Müller, K. J. 1956. Cephalopodenfauna und Stratigraphie des Oberdevons von Schleiz und Zeulenroda in Thüringen. Beiheft Geologisches Jahrbuch (Hannover) 20: 1-93.

Münster, G. 1839. Der Chiton priscus und einige andere seltene Versteinerungen aus der Uebergangs-Formation. - Beiträge zur Petrefacten-Kunde 1: 38-44; Bayreuth (Buchner). 
Pfeiffer, H. 1967. Stratigraphisches Korrelationsschema für das Devon der Deutschen Demokratischen Republik und angrenzender Gebiete. - Abhandlungen des Zentralen Geologischen Instituts (Berlin) 6: 1-74.

Racki, G., Racka, M., Matyja, H. \& Devleeschouwer, X. 2002. The Frasnian/Famennian boundary interval in the South Polish-Moravian shelf-basins: integrated event-stratigraphical approach. - Palaeogeography, Palaeoclimatology, Palaeoecology 181: 251-297.

Richter, R. \& Richter, E. 1926. Die Trilobiten des Oberdevon. Beiträge zur Kenntnis devonischer Trilobiten. IV. Abhandlungen der Preußischen Geologischen Landesanstalt, Neue Folge 99: 1-314.

Roemer, F. A. 1855. Beiträge zur geologischen Kenntniss des nordwestlichen Harzgebirges. III. - Palaeontographica 5 (1): $1-46,163-164$.

Sandberg, C. A.. Ziegler, W., Dreesen. R. \& Butler, J. L. 1988. Late Frasnian mass extinction; conodont event stratigraphy, global changes and possible causes. - Courier Forschungsinstitut Senckenberg 102: 263-307.

Schindewolf, O. H. 1921. Versuch einer Paläogeographie des europäischen Oberdevonmeeres. - Zeitschrift der Deutschen Geologischen Gesellschaft 73: 137-223.

Schlegel, G. \& Wiefel. H. 1998. Erläuterungen zur Geologischen Karte 1:25000 von Thüringen. Blatt Knau. Nr 5336; Blatt Schleiz, Nr. 5436. 2. Auflage. - Thüringer Landesanstalt für Geologie: 1-346: Weimar.

Schülke, I. 1995. Evolutive Prozesse bei Palmatolepis in der frühen Famenne-Stufe (Conodonta, Oberdevon). - Göttinger Arbeiten zur Geologie und Paläontologie 67: I-IV, $1-108$.

Sorauf, J. E. \& Pedder, A. E. H. 1986. Late Devonian rugose corals and the Frasnian-Famennian crisis. - Canadian Journal of Earth Sciences 23 (9): 1265-1287.

Soshkina, E. D. 1952. Opredelitel devonskikh chetyrekhluchevykh korallov. [Determination book of Devonian tetracorals]. - Trudy Paleontologicheskogo Instituta, Akademiva Nauk SSSR 39: 1-127.

Spalletta, C. \& Perri, M. C. 1998. Stop 2.2 - The FrasnianFamennian boundary at the Pramosio A section (Carnic Alps, Italy. - Giornale di Geologia, serie 3. 60 (Special Issue. ECOS VII Southern Alps Field Trip Guidebook): $198-205$.

Stainbrook, M. A. 1946. Corals of the Independence Shale of Iowa. - Journal of Paleontology 20 (5): 401-427.

Steinbach, W. 1974. Devon. In Hoppe, W. \& Seidel, G. (eds). Geologie von Thüringen: 208-256: H. Haack, Gotha/ Leipzig.
Volk, M. 1939. Das Oberdevon am Schwarzburger Sattel zwischen Südrandspalte und Kamm des Thüringer Waldes. Sitzungsberichte der physikalisch-medizinischen Sozietät Erlangen 70 (for 1938): 147-278.

Walch. J.E. I. 1769. Die Naturgeschichte der Versteinerungen zur Erläuterung der Knorrischen Sammlung von Merkwürdigkeiten der Natur. Zweyter Theil, zweyter Abschnitt. - [I-IV], 1-303; Paul Jonathan Felssecker, Nürnberg.

Weissermel, W. 1939. Die Korallen des thüringischen Devons. 1. Korallen aus Oberdevon im westlichen Schiefergebirge Thüringens. - Jahrbuch der Preußischen Geologischen Landesanstalt 59: 353-369.

Weyer, D. 1980. Zur Kenntnis seltener Petraiidae (Anthozoa, Rugosa) aus dem amerikanischen Obersilur. - Zeitschrift für Geologische Wissenschaften (Berlin) 8 (9): 1209-1216.

- 1981. Glatziella Renz 1914 (Ammonoidea, Clymeniida) im Oberdevon von Thüringen. - Hallesches Jahrbuch für Geowissenschaften 6: 1-12.

- 1984. Korallen im Paläozoikum von Thüringen. - Hallesches Jahrbuch für Geowissenschaften 9: 5-33.

- 1996. Nichlavalla sytovae n.g. n.sp. aus dem Lochkovian von Podolien (Anthozoa, Rugosa; Unterdevon, Ukraine) - Abhandlungen und Berichte für Naturkunde (Museum für Naturkunde Magdeburg) 19: 83-103.

- 2000. Revision der Gattung Czarnockia Różkowska 1969 (Anthozoa, Rugosa; Oberdevon). - Abhandlungen und Berichte für Naturkunde, Museum für Naturkunde Magdeburg 21: 75-107 (dated 1999, issued 16. 3. 2000).

Wever, D. \& Zagora, K. 1990. Die ehemalige Givet-Fossilfundstelle Büchenberg im Unterharz. - Hallesches Jahrbuch für Geowissenschaften 15: 21-42.

Wiefel, H. 1976. Die geologische Entwicklung der Lahn-DillErzlagerstätte Görkwitz bei Schleiz (Oberdevon und tiefes Dinant. Thüringisches Schiefergebirge). - Jahrbuch für Geologie (Zentrales Geologisches Institut Berlin), 1969/1970 5/6: $451-588$.

Ziegler, W. 1962. Taxionomie und Phylogenie oberdevonischer Conodonten und ihre stratigraphische Bedeutung. - Abhandlungen des Hessischen Landesamtes für Bodenforschung 38: 1-166.

Ziegler, W. \& Sandberg, C. A. 1990. The Late Devonian Standard Conodont Zonation. - Courier Forschungsinstitut Senckenberg 121: 1-115.

Zimmermann, E. 1915. Erläuterungen zur Geologischen Karte von Preußen und benachbarten Bundesstaaten. Lieferung 181. Blatt Schleiz. - Königlich Preußische Geologische Landesanstalt: 1-97. 